\title{
Screening of Occult Hepatitis B Virus Infection among Egyptian Blood Donors.
}

\author{
Attia Ahmed Attia ${ }^{1, *}$, Alaa Elmetwalli ${ }^{2}$ \\ ${ }^{I}$ Department of Microbiology, Faculty of Science, Benha University, Benha, Egypt. \\ ${ }^{2}$ Department of Clinical Trial Research Unit, Egyptian Liver Research Institute and Hospital, Mansoura, Egypt.
}

\begin{abstract}
Background: Although sensitive screening assays for hepatitis B virus surface antigen ( $\mathrm{HBsAg}$ ) are available, special cases of post-transfusion hepatitis B virus infection still occur. The present study was conducted to evaluate the prevalence of anti-hepatitis B core (anti-HBc) positivity and the presence of HBV-DNA in serum samples of healthy blood donors negative for both $\mathrm{HBsAg}$ and anti-HCV antibodies in Benha, Egypt.
\end{abstract}

Materials and methods: The study included a screening of 450 selected blood donors. The distribution of blood donors was 288 males (64\%) and 162 females (36\%). The recruited blood donors who met the criteria for blood donation were routinely screened for HBsAg, HIV I/2-Ab, and syphilisantibodies. The blood units for donations were further analyzed for the presence of HBc-IgM and HBV-DNA levels by PCR method.

Results: Testing of the accepted units for the donation was about $12(2.7 \%)$ HBc-IgM positive, and 9 (2\%) HBV-DNA positive units. The standard screening of blood unit failed to recognize early acute or window HBV infection where HBsAg is missing.

Conclusions: Our investigations proposed that sensitive methods for the detection of HBV by PCR might be recommended in the screening of donated blood. Furthermore, anti-HBc antibodies should be tested regularly on all blood donation units.

\section{Introduction}

In recent years, there has been increased community concern about the precautions of blood transfusion. HIV-1, HIV-2, hepatitis B and hepatitis C stay infectious causes by transfusion and are related to essential clinical illness ${ }^{1}$. The possibility of transfusion-transmitted hepatitis B virus (HBV) infection has been done by screening all blood donations for hepatitis B surface antigen (HBsAg) since $1970{ }^{2}$. Antibodies to hepatitis B core (HBc) antigen is the sign of acute, chronic, or resolved HBV infection and persist noticeable for lifespan ${ }^{3}$. These can be available without both HBsAg and anti-HBs antibodies, during the recuperating time frame following acute hepatitis $B$ before the presence of antibodies of $\mathrm{HBs}$, or in patients who

Keywords: Hepatitis B virus, blood transfusion, occult infection, polymerase chain reaction.

Received: 2-12-2020 ； Accepted: 21-2-2021

* Corresponding author. Email: aaa_attia2005@yahoo.com developed the disease. Antibodies to $\mathrm{HBc}$ are recognized in any individual who has been contaminated with $\mathrm{HBV}^{4}$.

The incubation period of HBV infection range from 45 to 160 days. After acute disease, the main virologic marker is the envelope protein and $\mathrm{HBsAg}$. As a rule, serum $\mathrm{HBsAg}$ can be gone before rises in serum transaminases as clinical side effects as well as stayed visible during the acute icteric period ${ }^{5}$. The HBsAg gets invisible 1 to 2 months following the beginning of jaundice. After HBsAg disappearance, the antibodies to HBsAg disclose in serum and stay perceptible 6.

There could be a lag period (window) between the disappearance of HBsAg and the presence of antibodies of HBsAg, during which time patients with HBV disease may not be distinguished by routine serologic testing. The hepatitis B core antigen ( $\mathrm{HBcAg})$ itself is sequestered inside the HBsAg coat and isn't typically perceptible in the serum of HBV-patients ${ }^{7}$. Antibodies to HBc (IgM), however, might be perceptible and can be used to recognize acute HBV disease during the window period ${ }^{8}$.

It has been shown that HBsAg negative people and those positives for antibodies to $\mathrm{HBc}$ keep on restoring $\mathrm{HBV}$. These discoveries recommended that convalescence from acute hepatitis B infection disease may not bring about complete infection, however rather the humoral immune response keeps the infection at a low level ${ }^{9}$.

It is known, in any case, that some blood subsidiaries, negative for HBsAg yet positive for antibodies against hepatitis $\mathrm{B}$ core antigen (anti-HBcAg), can transmit the disease, both after transfusion and after transplantation of organs ${ }^{10}$. HBcAg antibodies with no other HBV serological marker is as often as possible found in a various population. Various circumstances may represent this outcome falsepositive antibodies of $\mathrm{HBcAg}$ result; low degrees of $\mathrm{HBV}$ replication inside the hepatocyte, without evidence of $\mathrm{HBsAg}$; the window period of acute HBV disease; the loss of antibodies to HBsAg with time; or the nearness of an immunization get away from vaccine escape mutant, not recognized by the majority of available $\mathrm{HBsAg}$ detection tests ${ }^{11}$.

As per the sensitivity of polymerase chain reaction (PCR) technique has been improved, people assigning HBV DNA as the main marker of contamination have been discovered ${ }^{12}$. Occult hepatitis B disease is characterized as the presence of HBV DNA in the blood of hepatitis B surface antigen (HBsAg), with or without antibodies to hepatitis B core antigen (anti-HBc) or hepatitis B surface antigen (anti-HBs). Occult hepatitis B was found in 13-71\% 
of liver tissue and in $5-55 \%$ of sera from patients with chronic liver disease, who tested negative for HBsAg and antibodies to $\mathrm{HCV}^{13}$. To put it briefly, for the current study, we make an effort to test the eligible blood units for unraveling the acute HBV infection by using HBV-DNA level by PCR along with serological markers of blood donations.

\section{Materials and methods}

The study was carried out at the Regional Blood Transfusion Center (RBTC), Benha, Egypt, and movable blood collection vehicles through September 2019. Donors were questioned and physically inspected before blood transfusion. Persons who met donor collection conditions were designated for blood donation. Serum samples were stored at $-20^{\circ} \mathrm{C}$ pending procedure. It was conducted on 450 newly diagnosed healthy blood donors' volunteers.

\section{Routine serological assay}

All blood specimens were tested on a sequential basis for routine serological tests. The routine serological tests according to the predefined protocol of blood banking safety requirements by the Ministry of Health and Population (MOHP) issued 1994, comprised HBsAg, anti-HCV, and anti-HIV-1/2 as well. Detection of HBsAg was done using a commercially available ELISA kit (Axiom). HBsAgpositive samples were retested using a commercially available enzyme immunoassay kit (MonoLISA, Bio-RAD, France).

Detection of HCV-Ab was done using the commercially available $4^{\text {th }}$ generation ORTHO HCV ELISA test system. HCV-Ab-reactive samples were confirmed by antibodies against HCV ELISA kit, 4'h generation commercial kits (HCV; Abbott murex). Detection of anti-HIV-1/2 antibodies was done using a commercially available Bio-Rad GENSCREEN HIV-1/2 kit.

\section{Qualitative and Quantitative Analysis of HBV}

Eligible units for transfusion were tested for anti-HBc antibody IgM (HBc IgM) using commercially available Clinotech Diagnostics HBcAb IgM EIA $3^{\text {rd }}$ generation for the detection of IgM antibody. Detection of HBcAb IgM using DiaSorin kit was done to confirm positive samples detected by the Clinotech Diagnostics HBc IgM EIA kit. Detection of HBV-DNA was done using PCR. Briefly, 10 ul extracted DNA was added to a reaction mixture composed of 8 ul $10 \mathrm{mM}$ dNTP, 10 ul 10x Taq DNA polymerase buffer, $100 \mathrm{mmol}$ of outer sense ('5GTCTGTGCCTTCTCATCTGCC-3') and antisense C5AGAATAGCTTGCCTGAGTGC-3) primers, and $1 \mathrm{ul}$ (5U) Taq DNA polymerase. The reaction mixture was adjusted to 100 ul using $\mathrm{H}_{2} \mathrm{O}$. The amplification protocol was 4 minutes at $95^{\circ} \mathrm{C}$, followed by 30 cycles composed of $95^{\circ} \mathrm{C}$ for one minute (denaturation), $55^{\circ} \mathrm{C}$ for one minute (annealing), and $72^{\circ} \mathrm{C}$ for one minute (extension).

\section{Statistical analysis}

Data were analyzed using the SPSS computer program version 22.0. Quantitative data were expressed as means \pm standard deviation. Qualitative data were expressed as numbers and percentages. Chi-Square test and Fisher's Exact Test were used when appropriate for comparison between qualitative variables.

\section{Results}

The studied sample included 450 selected blood donors with 288 males and 162 females. Participation of volunteers were in urban residence 300 volunteers with percentage $(66.7 \%)$ and 150 volunteers from the countryside $(33.3 \%)$ as shown in (Table 1 ).

Donors of ages between 19 and 30 years constituted the largest proportion of males $(64 \%)$ and $36 \%$ of females were tested for the routine serological viral markers. All donors exhibited normal blood pressure, pulse rate, and were voluntary non-compensated blood donors, and were competent by a feedback form official by MOHP. All volunteers were tested for $\mathrm{HbsAg}, \mathrm{HCV}, \mathrm{HIV}$, and syphilis as prerequisites before blood donation, all tests came in the negative results (Table 2).

Out of all volunteers, and by furthered investigations, 12 samples $(2.7 \%)$ were reported as reactive for HBcIgM along 4 samples were positive for $\mathrm{HBeAg}$. According to an analysis of $\mathrm{HBeAb}$ and PCR came with positivity for $3(0.7 \%)$ and $9(2.0 \%)$ of volunteers respectively (Table 3$)$.

HBV-DNA by PCR was detected in 12/438 (33.3\%) donations. By comparison of results of $\mathrm{HBeAg}$ and $\mathrm{HBeAb}$ applied to $\mathrm{HBc} \operatorname{IgM}$ reactive, were positive in 4 samples $(33.3 \%)$ and negative in 8 samples $(66.7 \%)$ in $\mathrm{HBeAg}$. As per $\mathrm{HBeAb}, 3(25 \%)$ samples came positive and 9 samples (75\%) from 12 samples were positive in $\mathrm{HB}_{\mathrm{C}} \operatorname{IgM}$ (Table 4).

All volunteers who have been diagnosed with HBcIgM positive were classified according to Sociodemographic criteria (Table 5).

\section{Discussion}

Transfusion of infected blood by viral hepatitis is a major health problem. Screening blood donation for viral markers is an important source of information about the epidemiology of these infections ${ }^{14}$. The study was aimed to measure the age, sex, and blood group-specific prevalence of HBV in apparently asymptomatic healthy individuals donating blood. Consistent with routine practice, blood donor volunteers were questioned and medically inspected before contributing. Persons with high-risk behavior together with intravenous drug addicts, past of immoral sexual relations, homosexuals, or those with any medical problem particularly jaundice, bleeding disorders requiring constituent transfusion, pregnancy or recent delivery less than 12 weeks were disallowed ${ }^{15}$. Persons were also methodically asked about HBV vaccination. Recognized donors were regularly separated serologically for the presence of HBsAg, HCV-Ab, HIV-1/2-Ab, and Syphilis antibodies. Normally, negative donations for the above revealed serological markers are considered eligible for transfusion. It was found that among the accepted volunteers for donation Males outnumbered females in the present study group. 
Table 1. Socio-demographic variables of the studied blood donors.

\begin{tabular}{|c|c|c|}
\hline Variable & No. & Percentage (\%) \\
\hline Gender: & & \\
\hline Male & 288 & 64 \\
\hline Female & 162 & 36 \\
\hline Residence: & & \\
\hline Urban & 300 & 66.7 \\
\hline Rural & 150 & 33.3 \\
\hline Total & 450 & 100 \\
\hline
\end{tabular}

Table 2. Distribution of the blood donors according to serological tests for some diseases $(\mathbf{N}=450)$

\begin{tabular}{cccc}
\hline Serological test & $\begin{array}{c}\text { Reactive } \\
\text { No. }(\boldsymbol{\%})\end{array}$ & $\begin{array}{c}\text { Negative } \\
\text { No. }(\boldsymbol{\%})\end{array}$ & $\begin{array}{c}\text { Total } \\
\text { No. }(\boldsymbol{\%})\end{array}$ \\
\hline HBsAg & $0(0)$ & $450(100)$ & $450(100)$ \\
\hline HCVAb & $0(0)$ & $450(100)$ & $450(100)$ \\
\hline HIVAb1+2 & $0(0)$ & $450(100)$ & $450(100)$ \\
\hline Syphilis & $0(0)$ & $450(100)$ & $450(100)$ \\
\hline
\end{tabular}

Table 3. Distribution of blood donation according to the results of $\mathrm{HBsAg}$ negative $(\mathrm{N}=450)$

\begin{tabular}{cccc}
\hline HBV viral markers & $\begin{array}{c}\text { Reactive } \\
\text { No. }(\boldsymbol{\%})\end{array}$ & $\begin{array}{c}\text { Negative } \\
\text { No. }(\boldsymbol{\%})\end{array}$ & $\begin{array}{c}\text { Total } \\
\text { No. }(\boldsymbol{\%})\end{array}$ \\
\hline HBCIgM & $12(2.7)$ & $438(97.3)$ & $450(100)$ \\
\hline HBeAg & $4(0.9)$ & $446(99.1)$ & $450(100)$ \\
\hline HBeAb & $3(0.7)$ & $447(99.3)$ & $450(100)$ \\
\hline PCR & $9(2)$ & $441(98)$ & $450(100)$ \\
\hline
\end{tabular}

Table 4. Results of HBe Ag, HBe Ab, and PCR testing applied to HBC IgM reactive blood donors $(\mathrm{N}=12)$

\begin{tabular}{cccc}
\hline HBV viral markers & $\begin{array}{c}\text { Reactive } \\
\text { No. }(\%)\end{array}$ & $\begin{array}{c}\text { Negative } \\
\text { No. }(\%)\end{array}$ & $\begin{array}{c}\text { Total } \\
\text { No. }(\%)\end{array}$ \\
\hline HBe Ag & $4(33.3)$ & $8(66.7)$ & $12(100)$ \\
\hline HBe Ab & $3(25)$ & $9(75)$ & $12(100)$ \\
\hline PCR & $9(75)$ & $3(25)$ & $12(100)$ \\
\hline
\end{tabular}

Table 5. Distribution of HBC IgM reactive blood donors according to their Sociodemographic criteria $(\mathrm{N}=12)$.

\begin{tabular}{|c|c|}
\hline Sociodemographic criteria & Results \\
\hline \multicolumn{2}{|l|}{ Age } \\
\hline Mean \pm S.D. & $30.8 \pm 6.2$ \\
\hline Median(Range) & $30.50(23-40)$ \\
\hline \multicolumn{2}{|l|}{ Gender } \\
\hline Males N (\%) & $8(66.7)$ \\
\hline Females N (\%) & $4(33.3)$ \\
\hline \multicolumn{2}{|l|}{ Education } \\
\hline Undergraduate $\mathrm{N}(\%)$ & $1(8.3)$ \\
\hline Bachelor N (\%) & $5(41.7)$ \\
\hline Intermediate diploma N $(\%)$ & $6(50)$ \\
\hline \multicolumn{2}{|l|}{ Residence } \\
\hline Urban N (\%) & $6(50)$ \\
\hline Rural N (\%) & $6(50)$ \\
\hline
\end{tabular}


Out of 450 blood donors, $288(64 \%)$ were male and 162 $(36 \%)$ were female. This is in contrast to the study conducted by Said et al. in Egypt, where males (83.6\%) outnumbered females $(16.3 \%)$. This variance can be accounted for by the fact that in Egypt, females are less educated, socially less exposed, and are less enquired for blood donation. In consequence, there is a superior sum of male blood donors in study ${ }^{16}$. Our outcomes revealed that from the total 450 blood donor samples only $2.7 \%$ anti-HBc IgM was noticed. Acute hepatitis B is categorized by the concurrent existence of $\mathrm{HBsAg}$ and anti-HBc IgM. Through recovery, anti-HBc $\operatorname{IgM}$ is present during the window period within HBsAg disappearance and anti-HBs antibody ${ }^{17}$. These results are in agreement with the results of a recent study by Zhou et $a l^{18}$. The study showed $0.9 \%$ and $0.7 \%$ seroprevalence of $\mathrm{HBeAg}$ and $\mathrm{HBeAb}$ respectively among blood donors with $\mathrm{HBc}$ IgM positive test. The rate is comparable to that reported in Mohammed et al. that the highest prevalence of $37.5 \%$ (9/24) for HBeAg was found among blood donors within the age group 17- 26 years; blood donors within age group 27-36years had the lowest prevalence of $20.0 \%(2 / 10)$ while no HBeAg was detected among blood donors within the age group 47-56 years and $\geq 57$ years and the prevalence of $15.6 \%$ for Hepatitis B e antibody $\mathrm{HBeAb}{ }^{19}$. The factors showing these differences may be due to education, socioeconomic level, and awareness of the population. The occurrence may also vary according to the method designed for testing and the size of the sample taken in the study. Moreover, in the current study $9(2 \%)$ cases were positive for HBV-DNA. These cases were chosen negative for all serological markers used in this study. According to, the distribution of $\mathrm{HBc} \operatorname{IgM}$ reactive patients, the study showed that the mean age of total 12 positive HBcIgM was $30.8 \pm 6.2$ and the frequency of HBcIgM was found to be $66.7 \%$ in males and $33.3 \%$ in female's blood donors. A higher incidence in males than females could be for the reason that males more repeatedly volunteer for blood contribution. An additional reason could be that females do not achieve the minimum standards essential for blood contribution, this is in agreement with the study done by Japhet et al., (2011). The education level for those whom HBcIgM were positive appeared in intermediate education levels with equality in residence by $50 \%$ in both sexes ${ }^{20}$.

\section{Conclusion}

To sum up, screening for occult hepatitis B infection must be a routine practice in blood donors. Anti-HBc antibody tests should be included in routine tests done on blood donor volunteers to reduce HBV post-transfusion transmission.

\section{References}

1. Marenzoni, M. L., Lauzi, S., Miglio, A., et al. (2018). Comparison of three blood transfusion guidelines applied to 31 feline donors to minimise the risk of transfusion-transmissible infections. Journal of Feline Medicine and Surgery, 20(8), 663-673.
2. Gresens, C. J., and Holland, P. V. (1998). Current risks of viral hepatitis from blood transfusions. Journal of gastroenterology and hepatology, 13(4), 443-449.

3. Gerlich, W. H. (2013). Medical virology of hepatitis B: how it began and where we are now. Virology journal, 10(1), 1-25.

4. Ganczak, M., Topczewska, K., Budnik-Szymoniuk, M., et al. (2019). Seroprevalence of anti-HBc, risk factors of occupationally acquired HBV infection and HBV vaccination among hospital staff in Poland: a multicenter study. BMC public health, 19(1), 1-12.

5. Candotti, D., Assennato, S. M., Laperche, S., et al. (2019). Multiple HBV transfusion transmissions from undetected occult infections: revising the minimal infectious dose. Gut, 68(2), 313-321.

6. Makuza, J. D., Rwema, J. O. T., Ntihabose, C. K., et al. (2019). Prevalence of hepatitis B surface antigen (HBsAg) positivity and its associated factors in Rwanda. BMC infectious diseases, 19(1), 1-10.

7. Hollinger, F. B., and Sood, G. (2010). Occult hepatitis B virus infection: a covert operation. Journal of Viral Hepatitis, 17(1), 1-15.

8. Mulakoli, F. S. (2019). prevalence of occult hepatitis b virus infection in blood donors in nairobi city county, kenya: case of aga khan university hospital (Doctoral dissertation, Kenyatta University).

9. Zhang, L., Chang, L., Laperche, S., et al. (2019). Occult HBV infection in Chinese blood donors: role of $\mathrm{N}$ glycosylation mutations and amino acid substitutions in $\mathrm{S}$ protein transmembrane domains. Emerging microbes \& infections, 8(1), 1337-1346.

10. Abakar, A. E. M. (2018). Sero-molecular Epidemiology of Occult Hepatitis B Virus Infection among Haemodialysis Patients and Blood Donors, Gezira Hospital for Renal Diseases and Surgery, Gezira State, Sudan (2013-2017) (Doctoral dissertation, University of Gezira).

11. Gish, R. G., Basit, S. A., Ryan, J., et al. (2020). Hepatitis B Core Antibody: Role in Clinical Practice in 2020. Current Hepatology Reports, 1-12.

12. Wang, Y. Z., Xiao, J. H., Liu, L. G., et al. (2011). Simultaneous detection of hepatitis B virus genotypes and mutations associated with resistance to lamivudine, adefovir, and telbivudine by the polymerase chain reaction-ligase detection reaction. Brazilian Journal of Infectious Diseases, 15(6), 560-566.

13. Carton, J. (Ed.). (2017). Oxford handbook of clinical pathology. Oxford University Press.

14. Grabarczyk, P., Sulkowska, E., Gdowska, J., et al. (2018). Molecular and serological infection marker screening in blood donors indicates high endemicity of hepatitis E virus in Poland. Transfusion, 58(5), 12451253.

15. McCullough, J. (2016). Transfusion Medicine Paper. John Wiley \& Sons.

16. Said, Z. N., El Sayed, M. H., Salama, I. I., et al. (2013). Occult hepatitis B virus infection among Egyptian blood donors. World Journal of Hepatology, 5(2), 64.

17. Ie, S. I., Sidarta, E., Sadhewa, A., et al. (2015). High prevalence of hepatitis B virus infection in young 
adults in Ternate, eastern Indonesia. The American journal of tropical medicine and hygiene, 93(6), 13491355.

18. Zhou, K., and Zhou, S. (2020). Risk of disease transmission in an expanded donor population: the potential of hepatitis B virus donors. Current Opinion in Organ Transplantation, 25(6), 631-639.
19. Mohammed, N., Ashafa, A. M., and Aminu, M. (2020). Seroprevalence of Hepatitis B Virus e Antigen among Blood Donors in Kaduna State, Nigeria. International Journal Of Science for Global Sustainability, 6(3).

20. Japhet, M. O., Adesina, O. A., Donbraye, E., et al. (2011). Hepatitis B core IgM antibody (anti-HBcIgM) among hepatitis B surface antigen ( $\mathrm{HBsAg}$ ) negative blood donors in Nigeria. Virology journal, 8(1), 1-5. 